\title{
Renewable energy may fall off Britain's research agenda
}

London. British scientists working on renewable energy technology are awaiting a report that is expected to give their work a shot in the arm. That would be good news for a field whose future is clouded following the defeat in last month's general election of the government's main advocate of renewables, energy minister Colin Moynihan, and the dissolution of the Department of Energy.

Last August, Moynihan set up the Renewable Energy Advisory Group (REAG) following a commitment to do so by the Department of the Environment. At the time the group was said to be "spearheading the government's review of renewable energy", although since then there have been attempts to play down its importance.

The REAG was expected to deliver its report early this year, but the process was suspended because of the general election. It had already taken oral evidence from 18 organizations and written evidence from nearly 1,000 more, but has yet to reach any conclusions or recommendations.

No decision has yet been made by the Department of Trade and Industry (DTI), which has taken on most of the Department of Energy's duties, on whether the REAG report will be completed. Many energy commentators, including some who gave evidence to the REAG, fear that the work of the REAG will be buried.

However, other observers believe that a recent favourable report on renewable energy from the House of Commons Select Committee on Energy is an adequate com-

\section{Congress laments politics of energy}

Washington. An investigation by a US congressional committee has come to the unsurprising conclusion that politics, rather than merit and economic priorities, drives the US energy research programme.

At a hearing last week, the investigations subcommittee of the House of Representatives science committee released internal documents from the Department of Energy (DOE) that compared the agency's analysis of the relative merits of various energy research programmes with the amount of money it actually requested for those programmes for fiscal year 1993.

DOE's policy office ranked the programmes on the basis of their expected contributions to the goals of the National Energy Strategy - principally, reducing US demand for oil. Energy efficiency efforts came out on top across the board; ment. But this report, essentially an all-party commentary on the government's activities connected with renewables, lacks the potential impact of the REAG report, which was initiated by a minister and conducted within the department responsible for energy.

The transfer of energy policy, including research, from the Department of Energy to the DTI has itself caused dismay. Energy previously had high-level representation in the cabinet through the secretary of state for energy, who commanded a number of ministers, including Moynihan. Now there is just one minister for energy, Tim Eggar, whose time is expected to be taken up with selling off the UK coal industry and regulating the other privatized energy industries.

Although the select committee report was optimistic about the prospects for renewable energy in Britain - it recommended that the target for the annual contribution of renewables to the electricity supply by 2000 be raised from $1,000 \mathrm{MW}$ to between 3,000 and 4,000 MW - it attacked the government's handling of research and development into alternative energy technologies.

"In the past the Department [of Energy] has attempted to establish costs at too early a stage in a technology's development; to draw final conclusions from tentative assessments; and to place too little value on continuity of funding", the report said. "It is difficult to regard the history of renewable R\&D funding in the United Kingdom as other than a history of volte-faces, premature judgements and plain errors."

Ian Mundell

nuclear fission, fusion and fossil technologies were at the bottom. "Political sensitivities can be applied later," the head of the policy office wrote to the DOE secretary last July, "but you need to know, first, what seems to be right on the merits...."

However, after DOE applied those "political sensitivities', the picture was essentially reversed. The group given the highest priority was cut by an average of 52 per cent, and the group given lowest priority was increased by an average of 45 per cent.

One project that can thank politics for its funding is the Superconducting Super Collider. The policy office ranked the project second from the bottom as a basic research priority. But DOE ignored its recommendation to trim $\$ 100$ million from next year's proposed budget.

Christopher Anderson
Space station wins, but House critic says that he's lost it

Washington. While the planned space station Freedom was winning a vote of confidence last week, one of its harshest critics was announcing that he had had enough. Representative Bob Traxler (Democrat, Michigan) said he would not seek reelection next year after 18 years in the House of Representatives because he felt "powerless" to effect substantive change.

As chairman of the appropriations committee that determines the budgets of the National Aeronautics and Space Administration (NASA) and the National Science Foundation (NSF), Traxler was one of science's strongest supporters in Congress. But his efforts last year to kill the space station and use the money to fund research throughout the government - was defeated on the floor of the House after the Bush administration lobbied hard in its support.

Last week, that coalition of supporters held firm, defeating by a margin of 254 to 159 a proposal to kill the station and recover most of the $\$ 2,200$ million that NASA intends to spend on it next year. The vote to authorize NASA's programmes suggests that the lure of jobs and the excitement of space - two issues that supporters dwell upon are more persuasive arguments than an extensive lobbying campaign by professional societies for more useful research than that to be conducted on the space station.

Ray Bye, NSF's director of legislative affairs, called Traxler's decision to step down "a terrible loss for the agency and for science". Representative Louis Stokes (Democrat, Ohio) is expected to replace Traxler as the chair of the appropriations subcommittee, which includes the housing, veterans and environmental agencies as well as NASA and NSF. Stokes is known as a supporter of education, housing and minority issues.

A rash of retirements in both houses of Congress have claimed several other legislators who are active in science. Howard Wolpe (Democrat, Michigan), the chairman of the House science committee's investigations subcommittee, announced last month that he would leave at the end of his seventh two-year term. Wolpe reinvigorated the subcommittee and triggered recent investigations of the Superconducting Super Collider, NSF's manpower studies, the US energy research programme (see story at left) and NASA accounting procedures. Bye describes Wolpe as "our conscience". On the Senate side, Jake Garn (Republican, Utah), the ranking minority member of the NASA/NSF appropriations committee, a strong space advocate and the first legislator to fly on the space shuttle, has also announced his retirement.

Christopher Anderson 